\title{
Measuring the economic performance of socially responsible companies*
}

\author{
Josefina Fernández-Guadaño ${ }^{1}$
}

\begin{abstract}
The aim of this research is to use different economic variables to establish whether there are differences in economic performance between companies as a result of their inclusion in the sustainability index. This paper presents a one-dimensional exploratory study which compares the socially responsible companies included in the Spanish sustainability index, FTSE4Good Ibex, with the rest of the indices in the IBEX family. Parametric testing was used to study whether there are differences between the two types of companies. The results demonstrate that there are no statistically significant differences in economic performance between the two groups. Morover, it is confirmed that companies with good practices are as profitable as the rest, but it also demonstrates that the economic-financial behaviour is not better as a result of being in the sustainability index. The basic conclusion is that adhering to social and environmental standards does not harm a firm's competitive position and, therefore, provide support for the development policy of responsible practices so that they become a tool to help improve the resilience of the economy and investor trust.
\end{abstract}

Key words: Corporate social responsibility (CRS), corporate financial performance (CFP), Spain, sustainability index, good practices

JEL classification: M210, M400

\section{Introduction}

There is growing interest in Social Responsibility in both institutional and corporate circles, heightened, if that is possible, by recent developments in the financial crisis.

\footnotetext{
* Received: 01-10-2015; accepted: 15-12-2015

1 PhD in Economic science, Finance Department, Faculty of Economics Sciences Complutense University Campus Somosaguas, Pabellón de Sexto, Despacho 46, E-28223 Pozuelo de Alarcón, Madrid, SPAIN. Scientific affiliation: corporate finance. Phone: +34 913942 330. E-mail: jofernan@ucm.es.Website: http://www.ucm.es/ecfin3/fernandez-guadano,-josefina; http:// pendientedemigracion.ucm.es/info/eec/DetalleComponente.php? IdDeComponente $=30$.
} 
These developments have led to, among other things, a crisis of confidence in the current system, which could to some extent contribute to a return to good business practices. A commitment to Social Responsibility is a strategic factor in economic recovery and in sustainable development.

While the widespread conviction in the capitalist system in the recent past was that the only responsibility of a company was to maximise profits, with the only limit on behaviour being commercial law and customs, recent economic developments have increased the need for greater Corporate Social Responsibility (CSR).

In fact, CSR itself arose in part as a result of the shortcomings of the capitalist system. The view is that some changes are essential, such as making the system less economistic and more humanistic. This involves a greater level of regulation to combat the inequalities generated in a market economy. This can be done by incorporating values other than profit maximization into the management of the company, and enhancing the sustainability of business activities (Dobers and Halme, 2009). New initiatives are currently underway in Spain with regard to environmental policy, sustainable development, and stakeholder engagement in accordance with Law 2/2011 and the new Spanish Strategic Plan for CSR (20142020) within the framework of the Renewed EU strategy for Corporate Social Responsibility (European Commission, 2011).

In the past, upsurges of interest in CSR have been associated with social or economic shocks, such as the oil crisis of the 70s, the fall of the Berlin Wall in 1989 and the scandals during the financial bubble for Internet companies in the 2000s (Mozas and Puente, 2010; Gallardo et al., 2015). As a result, during the current financial crisis there has been renewed interest the good business practices derived from CSR to help restore confidence in the financial system (Charlo and Moya, 2010; Ruiz et al., 2009) and, by extension, the capitalist system.

There is a growing belief that environmental and social issues have an impact on the long-term success of companies and their competitive differentiation in the global market (FTSE, 2008). The Business Case for CSR argues that these policies can improve a company's competitiveness and, subsequently, its corporate economic and financial performance (Burke and Logsdon, 1996)

The pragmatic business case for CSR can be argued from many different viewpoints: solely to increase profit (Profit approach); to satisfy different stakeholders (Stakeholder approach); to build a positive reputation and brand image (Reputational approach); to do the "right thing" (Ethical approach); to contribute to long-term sustainable development (Sustainability approach) (Ditlev-Simonsen and Midttun, 2010). All of these perspectives include multiple issues and topics.

Financial results are one of the most commonly used rationales for supporting or criticising CSR because while there is an argument that it leads to greater profits, 
it is also recognised that the implementation of sustainable practices has associated costs. Previous empirical work has not found conclusive results in relation to CSR practices and the financial performance of companies (CFP) (Orlizky et al, 2003; Wu, 2006; Esteban and Benito-Hernández, 2015) and in any event it is accepted that these cannot be generalized to all markets and sectors (Soana, 2011; Server and Villalonga, 2005).

This paper thus aims to find additional empirical evidence by taking advantage of the fact that since 2008 the socially responsible companies in Spain are listed on a separate FTSE4Good Ibex sustainability index. This study compares the socially responsible companies included in this index with those in the rest of the indices in the IBEX family.

The hypothesis of this paper is to test whether there are no differences in economic and financial performance as a result of their inclusion in the sustainability index. If this can be shown, it could be used to justify an increased use of CSR practices in businesses and to provide information to people who wish to invest responsibly but want guarantees that they will not be penalized financially.

For testing our hypothesis, the remainder of the paper is structured as follows: the next section reviews the theoretical foundations that link CSR with business results; then, we focuses on the some business benefits of CSR and justification of the hypotheses that are empirically contrasted. The next section describes the methodology and Empirical data and analysis are presented in Section IV. In the penultimate section, the empirical results are presented, and finally, the conclusions section discusses the implications and limitations of the evidence found.

\section{Literature review}

The good practices derived from CSR are perceived as part of a renewed culture of industrial relations and innovative business strategies that seek to generate competitive advantages. Research on the relationship between CSR and financial performance began in the 1970s, but recent years have seen a proliferation of increasingly sophisticated papers that have found a positive, negative and neutral relationship. According to Simpson and Kohers (2002, p. 101) it is precisely the ability of researchers to provide a rationale for each of these three positions that demonstrates the need for a more unified theory and reliable empirical testing.

However, there seems to be more empirical evidence that corroborates the existence of a positive relationship between financial performance and the development of good CSR practices (Roman et al., 1999, Stanwick and Stanwick, 1998; Preston and O"Bannon, 1997; Nieto and Fernández, 2004; Michelon, Boesso et al., 2013; Muñoz, Sánchez de Pablo and Peña, 2015). Two meta-analyses conducted 
by Orlitzky, et al. (2003) and Frooman (1997) confirm the positive relationship, as well as the existence of a virtuous circle: good financial performance leads to a good level of CSP, which in turn contributes to improving the firm's financial performance.

However, critics of CSR cite efficiency problems arising from the fact that companies assume obligations or responsibilities beyond the simple generation of profit. Preston and O'Bannon (1997) highlight the "opportunistic managerial behaviour hypothesis" to explain the negative relationship between social and financial performance. This suggests that when financial performance is strong, managers will reduce expenditure on social performance because they can increase their personal compensation which is linked to short-term profitability. Conversely, when financial performance is poor, managers will attempt to divert attention by conspicuous expenditure on social programmes. The negative relationship between social and financial performance is consistent with the neoclassical economic argument that social performance causes the company to incur costs and reduces the profit for its partners, which in turns conflicts with its corporate responsibility (Friedman, 1962; Wright and Ferris, 1997; Henderson, 2001; Jensen, 2002).

Finally, the finding of a neutral (no) relationship is explained by the argument that the general situation of a firm and society is so complex that a simple, direct relationship between corporate social performance and financial performance does not exist (Waddock and Graves, 1997; McWilliams and Siegel, 2001; Soana, 2011).

According to Fifka (2013) it is remarkable that for Spain, Portugal as well as Italy the number of studies which did not find an influence of industry membership and financial performance on reporting is unusually high; in the case of Spain, an impact of financial performance could not be found on their firms. This paper, therefore, aims to find additional empirical evidence from Spain.

\section{Methodology}

Previous studies have tried to explain the interaction between CSR and CFP by identifying some of the mediating effects like CSR business benefits. Weber (2008) mentioned some CSR benefits found in studies by different authors. These included cost reduction (Epstein and Roy, 2001); competitiveness through process and product benefits (Rondinelli and London 2002); gains in profitability (Stanwick and Stanwick, 1998); increased access to capital and reduced capital costs (Heal 2005; Epstein and Roy 2001) and, risk management and reduction (Schaltegger and Wagner, 2006; Heal 2005; Hansen 2004).

Therefore, if CSR has any effect on financial performance, one of the best ways to measure it would be by examining various accounting and market based variables 
(Schreck, 2011). For this reason, this research aims to test hypotheses related to several factors: firstly, differences in economic or operating performance, which can indicate gains in relation to costs and competitiveness through process and product benefits; secondly, differences in profitability, which can point to benefits from more efficient investments and the improved use of financial resources; and, lastly, differences in financial performance, which measure the ease of access to capital, reduced capital costs and risk management.

According to Valor and Hurtado (2009) there is a positive correlation between good CSR practices (belonging to an ethical index) and the economic profit achieved (economic growth). Meanwhile, Thorpe and Prakash-Mani (2003) highlight that success factors for business sustainability include revenue growth, market access and cost savings. In an empirical study into several companies, Steger (2006) identifies the same benefits of CSR, among which are cost reduction and revenue growth.

According to Weber (2008) the monetary benefits of CSR include revenue growth, cost reduction and growth in brand value as measured from a financial perspective. In terms of costs what stands out are the savings derived from CSR measures that focus on the reduced use of resources or improved access to capital due to the growing sensitivity of investors to sustainability issues (Epstein and Roy, 2001). In relation to revenue growth based on high sales and market share, the benefits come from improved brand image, a product aimed at CSR or market development (Kong et al., 2002)

Following Herremans et al. (1993) profit before depreciation was used to avoid distortions arising from differing depreciation policies. EBITDA was chosen to include increased revenue, reduced costs, and to avoid the bias of depreciation and financial policies. This is one of the most established indicators, together with the Value Added, for measuring the operating profitability of a company.

To analyse the differences in economic performance a hypothesis was proposed for each of the three variables: EBITDA, Value Added and Profit per share.

ROA (Return on Assets) and ROE (Return on Equity) ratios have been used to study possible differences in profitability. After reviewing various studies published on socially responsible companies, Griffin and Mahon (1997) concluded that there appears to be a statistically significant relationship between socially responsible companies and profitability levels. Similarly, Stanwick and Stanwick (1998) found a positive correlation between corporate social performance and profitability in all six years (1987-1992) of their study, while Aupperle, Carroll and Hatfield (1985) found no relationship between the two. To analyse the differences in profitability, two hypotheses related to Economic and Financial Profitability were established. 
The study of possible differences related to strictly financial performance is carried out by contrasting three hypotheses based on solvency ratio, debt ratio and the beta coefficient or measurement of the systematic risk of the company. Schaltegger and Wagner (2006) find that one of the benefits of CSR to a business is advantages in financing and risk reduction. In turn, Heal (2005) emphasizes the reduction of the cost of capital, and Hansen (2004) finds an advantage through improved access to capital.

One variable in Roberts model was the debt/equity ratio, the argument being that the greater the degree to which a corporation relies on debt financing to fund capital projects, the greater the degree to which corporate management would be expected to respond to creditor expectations concerning a corporation"s role in social responsibility activities (Roberts, 1992). However, the results showed a zero correlation with social disclosure.

A number of studies have tested or controlled for risk (Moore, 2001). The argument here is that firms with a low level of systematic risk are more likely to be able to commit to social responsibility activities, and, vice versa, that firms with a high level of social responsibility activities may be viewed as better managed and therefore less risky (Roberts, 1992); Roberts study found the expected negative correlation between beta values and social disclosure at the 5\% level, as did McGuire et al. (1988); Herremans et al. (1993) also found that a good reputation for corporate social responsibility is strongly associated with lower total firm risk.

Trotman and Bradley (1981) however, found significantly higher beta values in companies that provided some social responsibility information over those that did not, and suggested that this could be because high systematic risk companies may perceive social responsibility as a means of reducing this risk. They also found no significant association between the systematic risk of a company and the amount of social responsibility information disclosed.

Therefore, to study possible differences related strictly to financial performance three aspects are studied related to the financial solvency, debt and systematic risk. To do so, parametric testing was used to study whether there are differences between the two types of companies, specifically Students T-test for independent samples, a technique which allows us to check for equality between measures, although some variables have required logarithmic transformations to achieve Normality.

In the paper we report the p-value associated with each test and the following decision rule, with a Type I error, $\alpha$, of 0.05: If $p$-value $>\alpha$ the null hypothesis of homogeneity between the firms is accepted and if $p$-value $<\alpha$ the null hypothesis of homogeneity between the firms is rejected. 


\section{Data and empirical analysis}

\subsection{Selection of the sample}

The company information used in the sample has been obtained by crossreferencing the accounting data available in the SABI database (http://www.bvdep. com/en/sabi.html) with the market data published by the Madrid Stock Exchange (www.bolsademadrid.es).

The companies in the sample were classified by distinguishing between socially responsible companies in the Spanish Sustainability Index, FTSE4Good IBEX, and those listed on the rest of the indices in the IBEX family. As the companies that are candidates to enter the FTSE4Good IBEX come from the IBEX 35 index and from indices for medium and small cap stocks, we focus on those companies that make up this sustainability index and those in the rest of the IBEX indices. In addition, previous empirical evidence shows the size variable to be significantly associated with social responsibility disclosure (Trotman and Bradley, 1981; Arlow and Gannon, 1982; Prado et al., 2008).

The sample has therefore been segmented on the basis of size using a classification that differentiates the large companies on the IBEX from the IBEX-Medium companies. The IBEX-Small companies were not included since the number of sustainable companies in this index over the period analysed is insignificant. Nor has it been possible to differentiate by sector of activity because not all the sectors are represented in the indices when classifying by size.

In 2008 the FTSE extended the Series of indices to include the FTSE4Good Ibex index for the Spanish market. The index includes companies from the Madrid Stock Exchange (BME) IBEX 35 Index and the FTSE Spain All Cap Index that meet the FTSE4Good inclusion requirements, namely compliance with Corporate Social Responsibility (CSR) standards ${ }^{2}$.

The inclusion criteria for the FTSE4Good are a set of constantly evolving CSR good practice standards. As new criteria are developed FTSE directly contacts the companies in the index to explain the new requirements and implementation deadlines. The inclusion criteria are totally transparent ${ }^{3}$ and based on a set of environmental (environmental management and climate change) and social (human and employment rights, labour standards in the supply chain and the reduction of bribes) standards ${ }^{4}$.

\footnotetext{
$\overline{2}$ Information available at: http://ftse.com.

3 The criteria can be downloaded at: http://www.ftse.com/Indices/FTSE4Good_IBEX_Index/Downloads/FTSE4Good_IBEX_Inclusion_Criteria.pdf.

${ }^{4}$ FTSE (2008) "FTSE4Good IBEX Index. Research and analysis report". Available on the Internet: http://www.ftse.com/Indices/FTSE4Good_IBEX_Index/Downloads/FTSE4Good_IBEX_Research_ Report_Spanish.pdf.
} 
Given the information provided by the Madrid Stock Exchange on the companies that make up the different stock market indices at the time the information was requested, and the available accounting information for the period analysed, 2008 and 2009, the sample consists of 43 companies: 22 are not in the sustainability index (11 large and 11 medium sized companies) and 21 are considered socially responsible (16 large and 5 medium). Although we are interested in using data from 2008 and 2009 to analyse the differences in the various economic variables, we also decided to observe the evolution of each variable over the immediately preceding years to detect possible changes following their entry into the sustainability index. As a result, the period covered by the study includes data from 2005 to 2009.

\subsection{Selection of the economic variables}

Theory unanimously recognizes a good proxy of CFP in accounting and market indexes (Soana, 2011). In our case, the variables have been grouped into three broad areas (Fernández-Guadaño, 2014), to compare the hypothesis proposed earlier, which include the following differences:

- Differences in the economic or operating performance of the company through the variables EBITDA (Earnings before interest, taxes, depreciation and amortization) and Value Added (Earnings from financial year + Corporation Tax + Staff Costs + Depreciation + Interest and similar charges), both standardised using Assets: EBITDA and Value-Added between Assets (EBITDA/A and VA/A) to avoid a size-bias, and Profit per share (Profit divided by number of shares).

- Differences in corporate profitability measured by Return on Assets (earnings before interest divided by total assets) and Return on Equity (earnings after interest divided by equity)- Differences in financial performance measured through ratios for financial solvency (Equity/Total liabilities), corporate debt ((Total liabilities and own capital - equity)/Total liabilities and Own capital) and the beta coefficient (measures the systematic risk of the profitability of a security in relation to changes in market returns).

\subsection{Empirical analysis}

In our study, Table 1 (see in Appendix) shows the p-values for the statistical testing of the hypothesis, differences in the economic performance of the companies as a result of their inclusion in the sustainability index, and Figure 1 shows the evolution of the ratio that represents the mean values of EBITDA/A for the companies included in the sustainability index compared to the mean values for the companies not in this index for the period 2005-2009, showing all companies, large companies and medium-sized companies separately. If the ratio is one the measures are equal, if it is greater than one the FTSEGood4 Ibex companies perform better than those on the Ibex and if it is less than one the opposite is true. 
Figure 1: Evolution of the average value ratio for the differences in the economic performance indicators

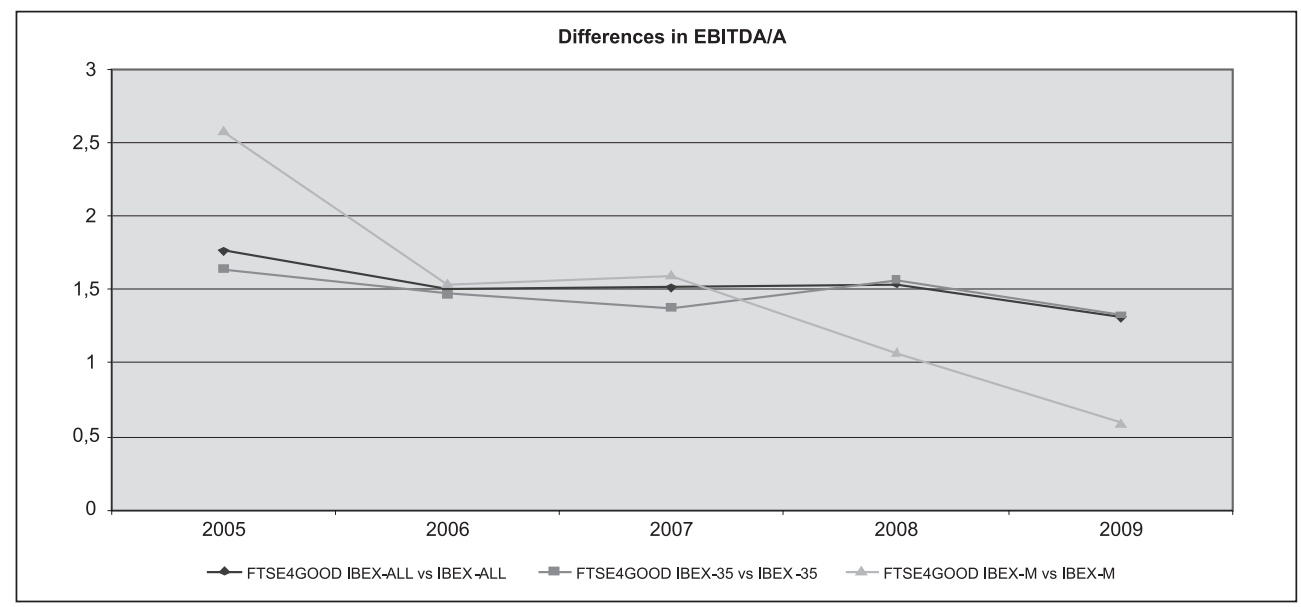

Source: Own elaboration

The EBITDA variable measured in relative terms (divided by Asset value) is not significantly different for companies inside and outside the sustainability index for all years studied in all groups ( $>$ > 0.05). The downward trend in 2008 and 2009 represents a lower operating profit per monetary unit invested which reduces the value of the ratio in recent years for all groups, although a comparison of the averages remains favourable for the companies in the sustainability index compared to those not, with the exception of medium-sized enterprises in 2009.

Table 2 (see in Appendix) shows the p-values from the statistical testing the hypothesis, differences in the economic performance of the companies as a result of their inclusion in the sustainability index using the Value Added variable in relative terms, and Figure 2 shows the ratio of the averages of the Value Added/A variable for the different types of company. We can see from Table 2 that significant differences do not exist when comparing companies inside and outside the sustainability index for all years studied and for all groups $(p>0.05)$. If you look at the evolution of the variable (figure 2), the decrease is precisely more pronounced during the last year. It is therefore possible, as in the case of EBITDA, to infer a reduction that is more drastic over this last year and more pronounced for large companies within the sustainability index. In any event, the comparison is always in favour of the companies in the FTSE4Good Ibex index. 
Figure 2: Evolution of the average value ratio for the differences in the economic performance indicators

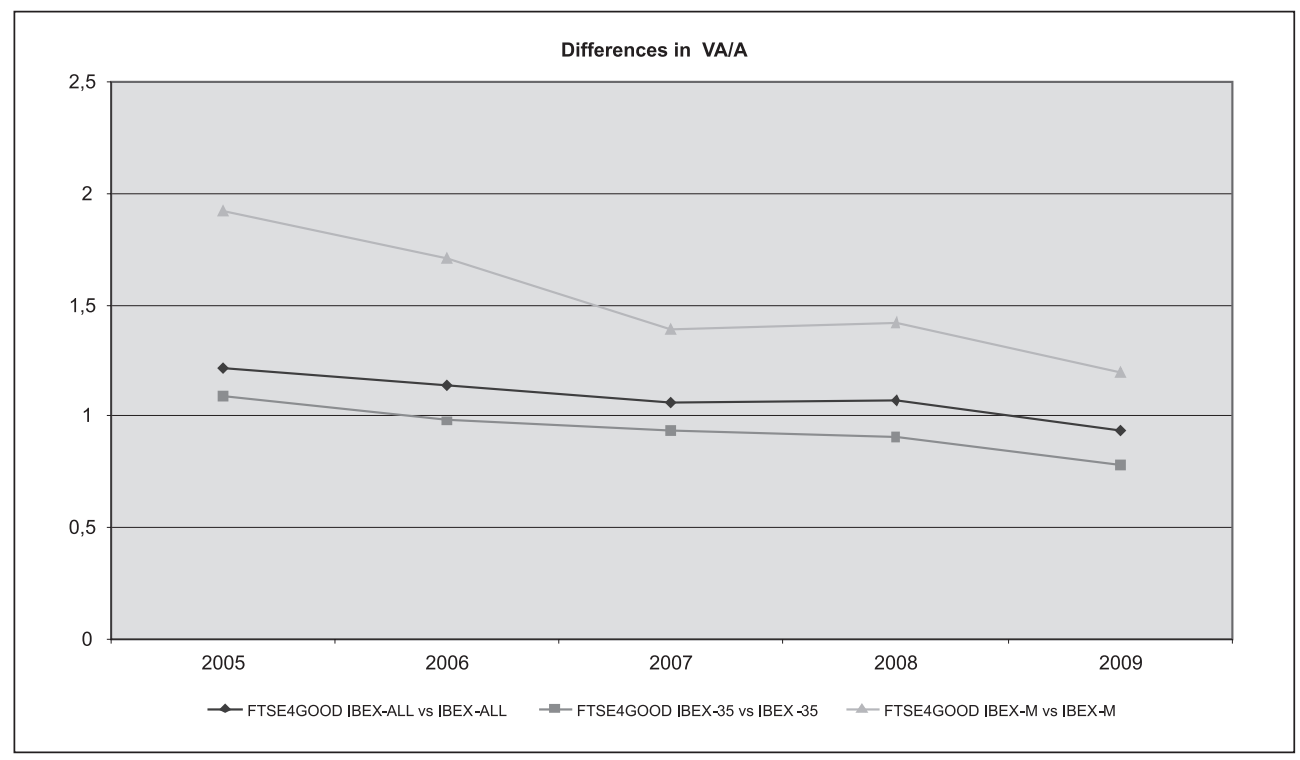

Source: Own elaboration

Charlo and Moya (2010) found that socially responsible companies have lower net profit per share in the Spanish market, with an average value of 0.90 compared to 1.31 for the companies from other indices included in the study. However, they also found that this difference was not statistically significant.

These results coincide with those obtained when we test hypothesis related with the differences in the economic performance of the companies as a result of their inclusion in the sustainability index, which are shown in Table 3 for the profit per share variable (see in Appendix) and demonstrate that there are no significant differences in this variable when comparing the two groups $(p>0.05)$. The average ratio shows (figure 3) a more pronounced downward trend starting in 2007, coinciding with the start of the financial crisis, and since 2006 the average values have been more favourable for the companies that are not in the index. 
Figure 3: Evolution of the average value ratio for the differences in the economic performance indicators

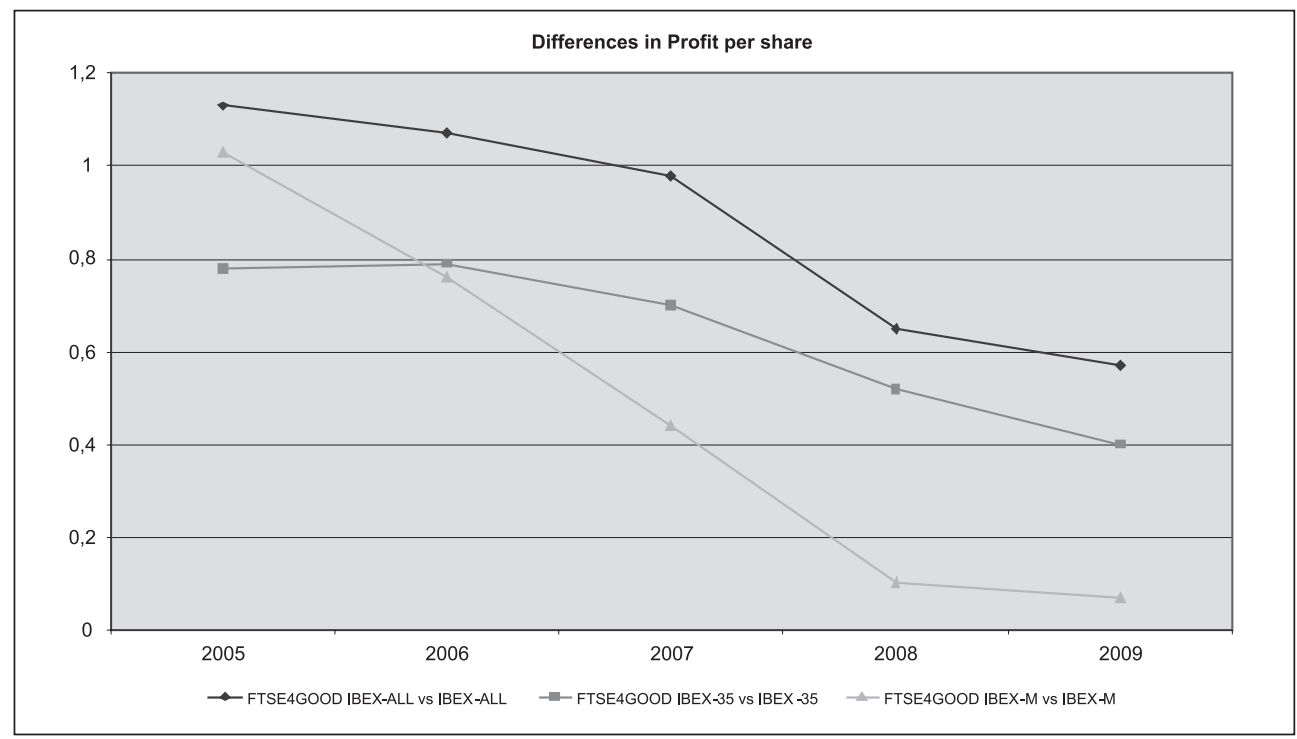

Source: Own elaboration

The differences in ROA (see table 4 in Appendix) between the companies in the sustainability index and those outside it can only be seen in $2005(\mathrm{p}<0.05)$ for all companies taken together. In that year the average ratio shows better results for the socially responsible companies.

If we examine the evolution of the average ROA ratio (figure 4) we can see that despite this downward trend the comparison is favourable to the responsible companies for all years, except for the last year analysed in the case of mediumsized enterprises. Also noteworthy is the marked downward trend in this year, which is caused in part by the adverse economic circumstances which tend to affect medium-sized companies more. 
Figure 4: Evolution of the average value ratio for the differences in the profitability indicators

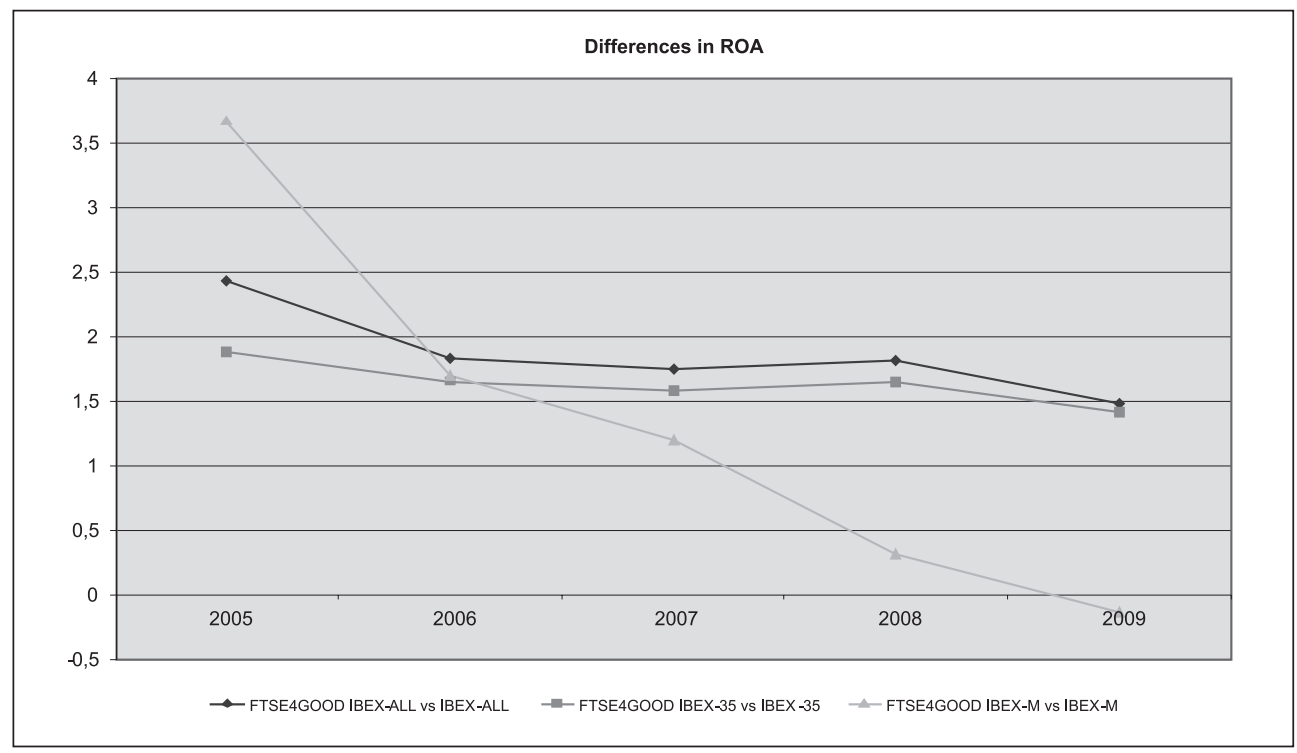

Source: Own elaboration

As can be seen from the data in Table 5 (see in Appendix), no significant differences in ROE between the two groups of companies were found, except when we consider all the companies as a whole for the year 2005, with $p<0.05$. In that year the average ratio was better for socially responsible companies.

The evolution of the average ratio (figure 5) is worse for medium-sized companies, and even changes from being favourable for the responsible companies to showing the opposite relationship over the final two years. Large companies have a more stable evolution in favour of responsible companies over all years and have made a major effort for their shareholders over the last two years. 
Figure 5: Evolution of the average value ratio for the differences in the profitability indicators

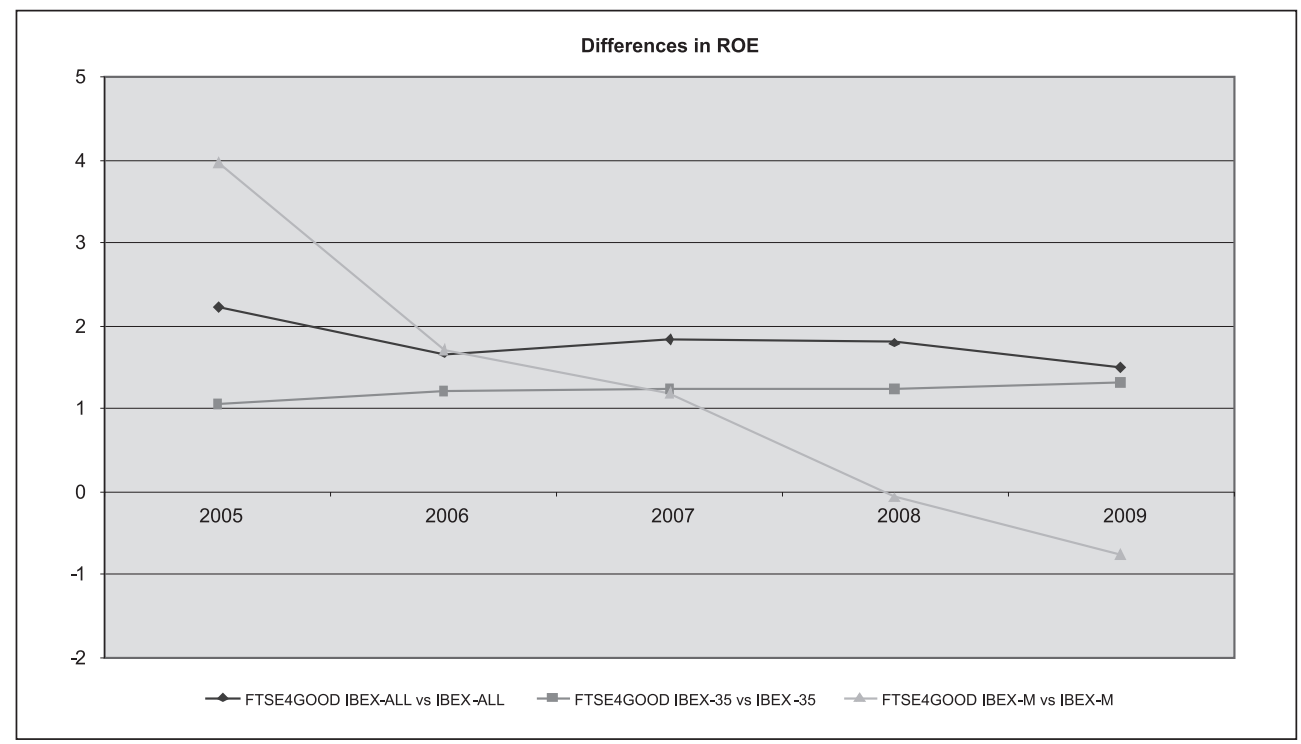

Source: Own elaboration

There are no differences in financial solvency between the two groups of companies for any year, regardless of whether they are differentiated by size or not $(p>0.05)$ (see table 6 in Appendix). Figure 6 compares the average values of both types of company and shows that the solvency ratio is higher over the entire period analysed for large companies compared to those of a medium size, and, in the first case, in favour of the companies in the sustainability index compared to those outside it in the case of the medium-sized companies. No substantial differences in the variable or in its behaviour were found that could be attributed to their inclusion in the index when comparing the companies for the years being studied, 2008 and 2009. 
Figure 6: Evolution of the average value ratio for the differences in the financial structure indicators

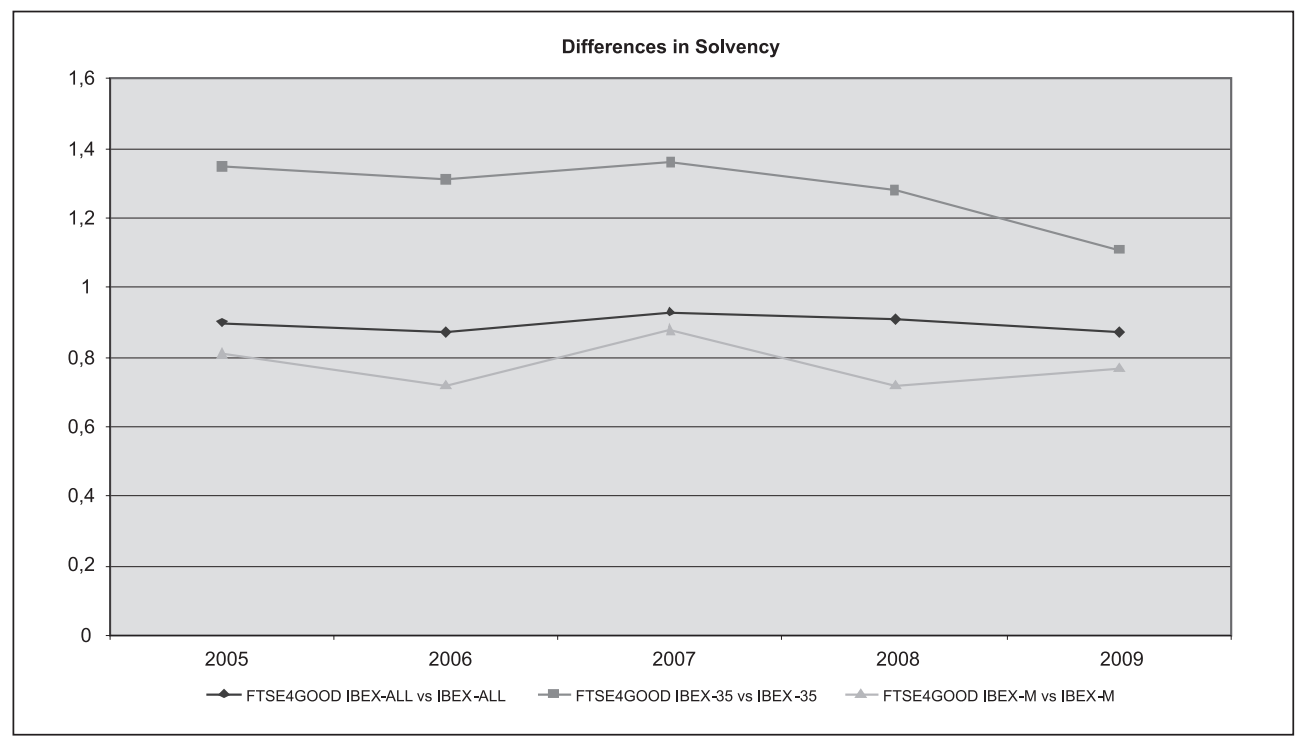

Source: Own elaboration

No statistically significant differences were found in the debt ratio (see table 7 in Appendix) between the two groups of companies being compared, and this is true for all groups and all years $(\mathrm{p}>0.05)$. The evolution of the average debt ratio (figure 7) that compares the companies inside and outside the sustainability index is higher for the medium-sized companies than the large companies. In other words, the large companies in the sustainability index perform better than companies not in this index because their average debt ratio is lower, while the opposite is true for medium sized companies. 
Figure 7: Evolution of the average value ratio for the differences in the financial structure indicators

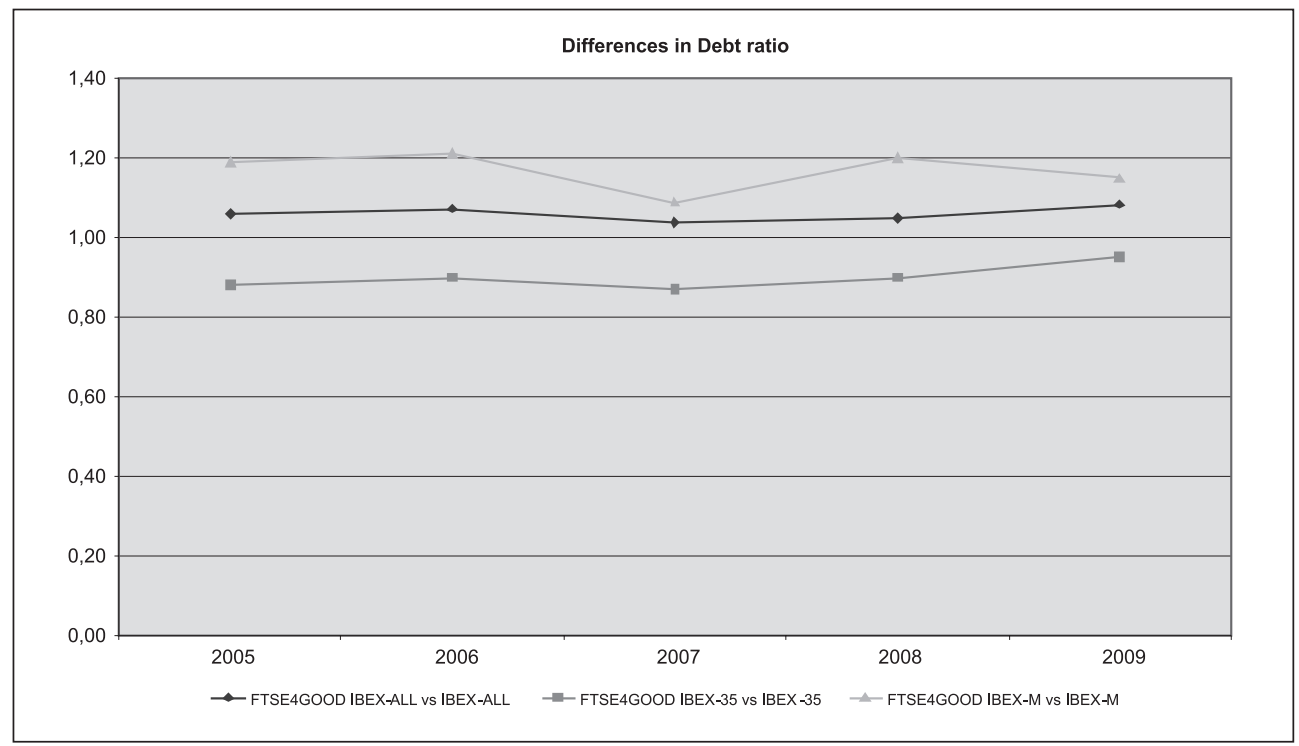

Source: Own elaboration

According to the study by Charlo and Moya (2010) for the Spanish market, companies in the FTSE4Good IBEX index had an average higher systematic risk, were more sensitive to market fluctuations and thus provided a greater market premium. However, given their average value it was concluded that investments had not been too aggressive and that they could be considered to be defensive companies in the face of bear markets.

In our case we can see differences (see table 8 in Appendix) between the two groups of companies for all the years, but, if we differentiate between the large and the medium-sized companies the differences are diluted. 
Figure 8: Evolution of the average value ratio for the differences in the financial structure indicators

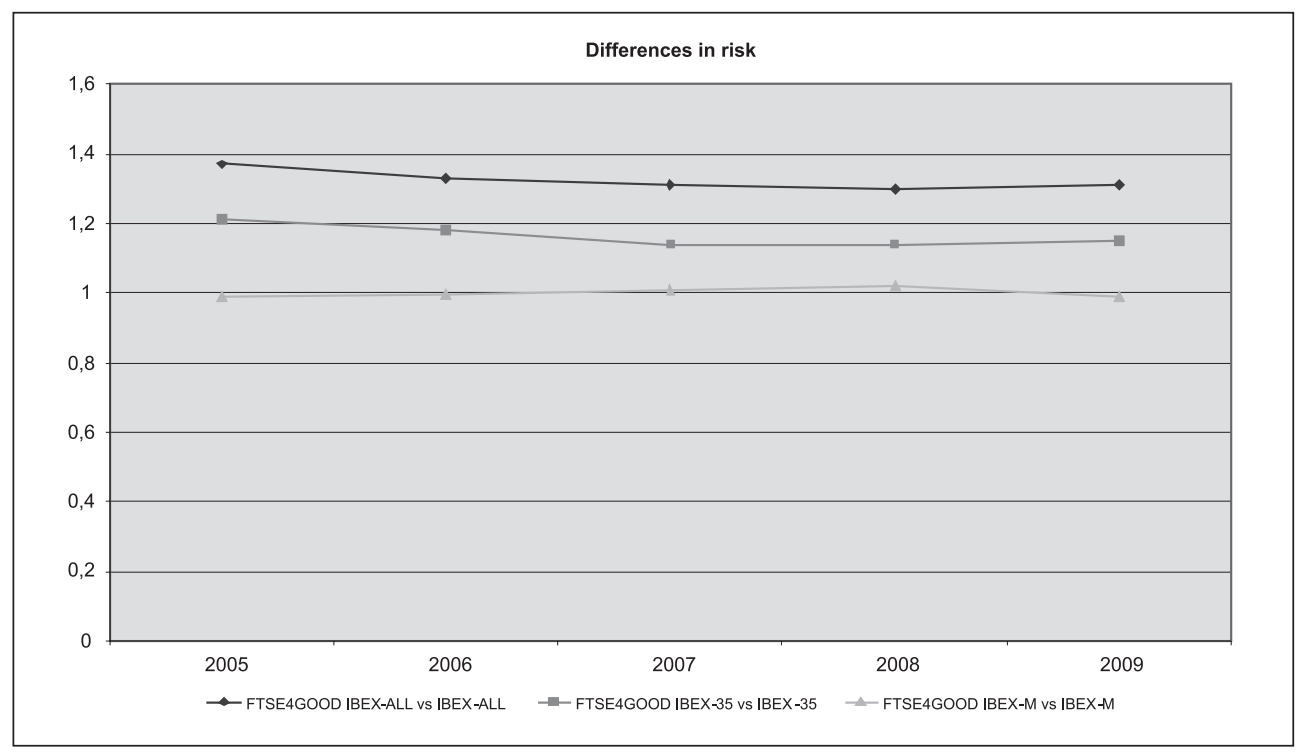

Source: Own elaboration

If we see the evolution of the average value ratio in figure 8 , the trend is the same: higher beta for companies in the sustainability index showing major differences large companies facing the medium companies whose average ratio is close to one in every year.

\section{Results and discussion}

Results of the research, for the period 2005-2009, show that economic performance, using variables EBITDA and VA standardised by Assets, is always in favour of the companies in the FTSE4Good Ibex index although the differences found are not statistically significant. The trend of both indicators during this period, in all groups, it is decreasing and more pronounced during the past two years, coinciding with the start of the financial crisis. The same evolution is for the profit per share ratio, but in this case, since 2006 the average values have been more favourable for the companies that are not in the sustainability index although the differences are not significant, these results agree with those found by Charlo and Moya (2010) for the Spanish market. In this case, this poor result in terms of the behaviour of this ratio cannot be attributed to entry into the sustainability index since the downward trend started before this took place. 
This study does not find any significant differences in profitability when comparing the two groups of companies, for either ROA or ROE, which is in keeping with the findings of Aupperle, Carroll and Hatfield (1985) who also failed to find a relationship between social responsibility and profitability.

According to a study by Charlo and Moya (2010) on the Spanish market, the profitability obtained by the owners of the companies in the responsibility index, measured using Return on Equity, has an average value of $16.27 \%$, greater than the $16.25 \%$ for companies in other indices. However, the result of the analysis demonstrates that no statistically significant differences between the two values were found $(\mathrm{p}>0.05)$. As in our case, the best results of both ratios, ROA and ROE, in favour of companies in the FTSE4Good Ibex index, are not statistically significant differences.

Finally, with respect to financial performance, measured through ratios for financial solvency and corporate debt, no statistically significant differences were found except for the systematic risk. In our case, the higher beta for companies in the sustainability index, coinciding with the results found by Charlo and Moya (2010) and Trotman and Bradley (1981) but differ from the theoretical foundations found in other studies such as Roberts (1992) and Herremans et al. (1993). However, the larger risk attributed to companies in the sustainability index is found not only in the years being studied, 2008 and 2009, but also in the preceding years, which leads us to conclude that, on the one hand, the differences cannot be attributed to their inclusion in the sustainability index, but, on the other hand, nor does their inclusion in it reduce the risk.

\section{Conclusions}

In general, the hypothesis tested have confirmed our initial aim of demonstrating that there are no statistically significant differences in economic and financial performance when comparing companies included in the FTSE4Good Ibex and those in the rest of the IBEX indices. These findings can contribute to the empirical literature and research debate related to the benefits of the CSR.The obtained results of the research confirms that companies with good practices are as profitable as the rest, but it also demonstrates that the economic-financial behaviour is not better as a result of being in the sustainability index. No differences were found in economic performance by comparing EBITDA/A and VA/A variables for the two samples of firms in any year and in any group. Also, no differences were found in the profitability, either economic or financial, of the two groups of companies. No differences were found in financial solvency or debt. Lastly, the systematic risk of the securities of the companies compared differ from the theoretical foundations found in other studies, but are consistent with those for other analyses performed 
on the Spanish market. Statistically significant differences between the two groups of companies were found for all years, but when size is taken into account these differences are diluted. The higher market risk attributed to companies in the sustainability index does not only take place in the years being studied, 2008 and 2009, but also in the preceding years, which leads us to conclude that the differences cannot be attributed to their entry into the sustainability index, nor does their inclusion reduce the risk. Despite the fact that our findings do not show statistically significant differences in economic performance between the two groups of companies, the current widespread use of social and environmental indices makes it difficult for Spanish firms to ignore this and not make efforts to improve their stakeholder relations. Furthermore, the legislation has progressively toughened corporate governance and reporting standards for firms that trade on the Spanish Index. However, the relatively restricted availability of time series data imposed certain restrictions on the empirical analysis. Such problems might be mitigated if more years were added to the time series and the IBEX-Small companies are included, forming an excellent basis for enriching future analyses. These results contribute additional proof that adhering to social and environmental standards does not harm a firm's competitive position and, therefore, provide support for the development policy of responsible practices so that they become a tool to help improve the resilience of the economy and investor trust.

\section{References}

Arlow, P., Gannon M. (1982) "Social Responsiveness, Corporate Structure, and Economic Performance", Academy of Management Review, Vol. 7, No. 2, pp. 235-241, doi: 10.5465/amr.1982.4285580.

Aupperle, KE, Carroll, AB, Hatfield, J. (1985) "An Empirical Examination of the Relationship between Corporate Social Responsibility and Profitability". Academy of Management Journal Vol. 28, No. 2, pp. 446-463, doi: 10.2307/25610.

Bowman, E., Haire, M. (1975) "A Strategic Posture Toward Corporate Social Responsibility”, California Management Review, Vol. 18, No. 2, pp. 49-58, doi: 10.2307/41164638.

Burke, L.,Logsdon, J. M. (1996) "How corporate social responsibility pays off". Longe Range Planning, Vol. 29, No. 4, pp. 495-502, doi: 10.1016/00246301(96)00041-6.

Charlo, M.J., Moya, I. (2010) "El comportamiento financiero de las empresas socialmente responsables", Investigaciones Europeas de Dirección y Economía de la Empresa Vol. 16, No. 2, pp. 15-25, doi: 10.1016/s1135-2523(12)60109-9.

Dobers, P., Halme, M. (2009) "Corporate social responsibility and developing countries”. Corp. Soc. Responsib. Environ. Mgmt, Vol. 16, No. 5, pp. 237-249, doi: $10.1002 /$ csr.212. 
Ditlev-Simonsen, C.D., Midttun, A. (2011) "What motivates managers to pursue corporate responsibility? a survey among key stakeholders". Corp. Soc. Responsib. Environ. Mgmt, Vol. 18, No. 1, pp 25-38, doi: 10.1002/csr.237.

Epstein, MJ., Roy, MJ. (2001) "Sustainability in action: Identifying and measuring the key performance drivers", Long Range Planning, Vol. 34, No. 5, pp. 585604, doi: 10.1016/S0024-6301(01)00084-X.

European Commission (2011) Communication from the Commission to the European Parliament, the Council, the European Economic and Social Committee and the Committee of the Regions A renewed EU strategy 2011-14 for Corporate Social Responsibility. COM/2011/0681 final.

Esteban, P., Benito-Hernández, S. (2015) "CSR Policies: Effects on Labour Productivity in Spanish Micro and Small Manufacturing Companies", Journal of Business Ethics, Vol. 128, No. 4, pp. 705-724, doi: 10.1007/s10551-013-1982-x.

Fernández-Guadaño, J. (2014) "Employee-owned and capitalist firms: is performance linked to ownership?", Service Business. An International Journal, Vol. 8, No. 4, pp. 541-558, doi: 10.1007/s11628-013-0206-x.

Fifka, MS. (2013) "Corporate Responsibility Reporting and its Determinants in Comparative Perspective - a Review of the Empirical Literature and a Metaanalysis". Bus. Strat. Env. Vol. 22, pp. 1-35, doi: 10.1002/bse.729.

Friedman, M. (1962) Capitalism and freedom. University of Chicago Press, Chicago.

Frooman, J. (1997) "Social Irresponsible and Illegal Behavior and Sahareholder Wealth", Business and Society, Vol. 36, pp. 221-249, doi: 10.1177/000765039703600302.

FTSE (2008) Índice FTSE4Good IBEX. Informe de Investigación y análisis. Avaible at: http://www.ftse.com/Indices/FTSE4Good_IBEX_Index/Downloads/ FTSE4Good_IBEX_Research_Report_Spanish.pdf.

Gallardo, D., Sánchez, M.I, Castilla, F. (2015) "Theoretical and Methodologial Framework for the Qualitative Validation of an Explanatory Model of Social Responsibility in Cooperative Societies", Revesco. Revista de Estudios Cooperativos, Vol. 118, No. 2, pp. 86-121, doi: 10.5209/rev_REVE.2015. n118.49058.

Griffin, J., Mahon, J. (1997) "The Corporate Social Performance and Corporate Financial Performance Debate. Twenty five years of Incomparable Research", Business and Society, Vol. 36, No. 1, pp. 5-31, doi: 10.1177/000765039703600102.

Hansen, U. (2004) "Gesellschaftliche Verantwortung als Business Case: Ansätze, Defizite und Perspektiven der deutschsprachigen Betriebswirtschaftslehre", in: Schneider, U. \& Steiner, P. (ed.) Betriebswirtschaftslehre und gesellschaftliche, Verantwortung: Mit Corporate Social Responsibility zu mehr Engagement, Wiesbaden: Gabler, $1^{\text {st }}$ edition, pp. 59-83, doi: 10.1007/978-3-322-90531-4 4.

Heal, G. (2005) "Corporate social responsibility: An economic and financial framework", The Geneva papers on risk and insurance - Issues and practice, Vol. 30, No. 3, pp. 387-409, doi: 10.2139/ssrn.642762. 
Henderson, D. (2001) Misguided Virtue: False Notions of Corporate Social Responsibility. London: Institute of Economic Affairs.

Herremans, I, Akathaporn, P., McInnes. M. (1993) "An Investigation of Corporate Social Responsibility Reputation and Economic Performance", Accounting, Organizations and Society, Vol. 18, No. 7/8, pp. 587-604, doi: 10.1016/03613682(93)90044-7.

Jensen, M. C. (2002) "Value Maximization, Stakeholder Theory, and the Corporate Objective Function", Business Ethics Quarterly, Vol. 12, No. 2, pp. 235-256, doi: $10.2307 / 3857812$.

Kong, N, Salzmann, O, Steger, U., Ionescu-Somers, A. (2002) "Moving business/ industry towards sustainable consumption: The role of NGOs", European Management Journal, Vol. 20, No. 2, pp. 109-127, doi: 10.1016/S02632373(02)00022-1.

McGuire, J B, Sundgren,A., Schneeweis, T. (1988) Corporate Social Responsibility and Firm Financial Performance, Academy of Management Journal Vol. 31, No. 4, pp. 854-872, doi: 10.2307/256342.

McWilliams, A., Siegel, D. (2001) "Corporate Social Responsibility: A Theory of the Firm Perspective", Academy of Management Review Vol. 26, No. 1, pp. 117-127, doi: 10.5465/AMR.2001.4011987.

Michelon, G. and Boesso, G., Kumar, K. (2013) "Examining the Link between Strategic Corporate Social Responsibility and Company Performance: An Analysis of the Best Corporate Citizens", Corp. Soc. Responsib. Environ. Mgmt, Vol. 20, No. 2, pp. 81-94, doi: 10.1002/csr.1278.

Moore, J. (2001) "Corporate Social and Financial Performance: An Investigation in the U.K. Supermarket Industry", Journal of Business Ethics, Vol. 34, pp. 299 315, doi: 10.1111/1467-8608.00256.

Mozas, A., Puente, R. (2010) "Corporate Social Responsability and its parallelism with the cooperative societies", Revesco. Revista de Estudios Cooperativos, Vol. 103, No. 3, pp. 75-100.

Muñoz, R., Sánchez, P., Peña, I. (2015) "Linking corporate social responsibility and financial performance in Spanish firms", European J. International Management, Vol. 9, No. 3, pp. 368-408, doi: 10.1504/EJIM.2015.069133.

Nieto, M., Fernández, R. (2004). "Responsabilidad Social Corporativa: la última innovación en management”, Universia Business Review, Vol. 1, pp. 28-39.

Orlitzky, M, Schmidt,FL., Rynes, SL. (2003) "Corporate social and financial performance: a Meta-analysis”. Organization Studies Vol. 24, No. 3, pp. 403441. doi: $10.1177 / 0170840603024003910$.

Prado, JM, Gallego, I., García, I.M., Rodríguez, L. (2008) "Social Responsabilty in Spain", Management Decision, Vol. 46, No. 8, pp. 1247-1271, doi: 10.1108/00251740810901417. 
Preston, LE., O’Bannon, DP. (1997) “The Corporate Social-Financial Performance Relationship: A Typology and Analysis", Business and Society, Vol. 36, No. 4, pp. 419-429, doi: 10.1177/000765039703600406.

Roberts, R. (1992) "Determinants of Corporate Social Responsibility Disclosure: An Application of Stakeholder Theory", Accounting, Organizations and Society Vol. 17, No. 6, pp. 595-612, doi: 10.1016/0361-3682(92)90015-K.

Roman, RM, Haybor S., Agle, BR. (1999) "The relationship Between Social and Financial Performance", Business and Society Vol. 38, pp. 397-418, doi: 10.1177/000765039903800105.

Rondinelli, D.A, London, T. (2002) "Stakeholder and corporate responsibilities in cross-sectoral environmental collaborations: Building value, legitimacy and trust". In: Andriof, J, Waddock, S, Husted, B., Sutherland Rahman, S. (Eds) Unfolding stakeholder thinking: Theory responsibility and engagement, Greenleaf, pp. 201-216.

Ruiz, M, Ríos, A., Tirado, P. (2009) "Social Responsability and Economic Crisis. Do financial institutions respond to stakeholders?", Ciriec-España. Review of Public Economic, Social and Cooperative, Vol.65, pp. 33-58.

Schaltegger, S., Wagner, M. (2006) "Managing and measuring the business case for sustainability: Capturing the relationship between sustainability performance, business competitiveness and economic performance". In: Schaltegger, S, Wagner, M. (eds). Managing the business case for sustainability: The integration of social, environmental and economic performance, Sheffield, Greenleaf, pp. 1-27.

Schreck, P. (2011) "Reviewing the Business Case for Corporate Social Responsibility: New Evidence and Analysis", Journal of Business Ethics (2011), Vol. 103, No. 2, pp. 167-188, doi: 10.1007/s10551-011-0867-0.

Server, R., Villalonga, I. (2005) "Corporate Social Responsibility (CSR) and its Integrated Management", Ciriec-España. Journal of Public, Social and Cooperative Economy, No. 53, pp. 137-161.

Simpson, W.G., Kohers, T. (2002) "The Link Between Corporate Social and Financial Performance: Evidence from the Banking Industry", Journal of Business Ethics Vol. 35, pp. 97-109, doi: 10.1023/A:1013082525900.

Soana, M.G. (2011) "The relationship between Corporate Social Performance and Corporate Financial Performance in the Banking Sector", J Bus Ethics Vol. 104, pp. 133-148, doi: 10.1007/S10551-011-0894-X.

Stanwick, P.A., Stanwick, DS. (1998) "The Relationship Between Corporate Social Performance and Organizational Size, Financial Performance and Environmental Performance: An Empirical Examination", Journal of Business Ethics Vol. 17, pp. 95-204, doi: 10.1007/978-94-007-4126-3_26.

Steger, U. (2006) Building a business case for corporate sustainability. In: Schaltegger, S, Wagner, M. (eds). Managing the business case for sustainability: 
The integration of social, environmental and economic performance, Sheffield, Greenleaf, pp. 412-443, doi: 10.9774/gleaf.978-1-907643-25-5 24.

Thorpe, J., Prakash-Mani, K. (2003) "Developing value: The business case for sustainability in emerging markets", In: Schaltegger, S, Wagner, M. (eds). Managing the business case for sustainability: The integration of social, environmental and economic performance, Sheffield, Greenleaf , pp. 444464(21), doi: 10.977/gleaf.978-1-907643-25-5 24.

Trotman, A., Bradley, G. (1981) "Associations between Social Responsibility Disclosure and Characteristics of Companies", Accounting, Organizations and Society Vol. 6, No. 4, pp. 355-362, doi: 10.1016/0361-3682(81)90014-3.

Valor, C., Hurtado, I. (2009) Las empresas españolas y la responsabilidad social corporativa. La contribución a los objetivos de desarrollo del Milenio. Los libros de la Catarata, Madrid.

Waddock, SA., Graves, SB. (1997) "The Corporate Social Performance-Financial Performance Link", Strategic Management Journal Vol. 18, No. 4, pp. 303319, doi: 10.1002/(SICI)1097-0266(199704).

Weber, M. (2008) "The business case for corporate social responsibility: A company-level measurement approach for CSR". European Management Journal, Vol. 26, No. 4, pp. 247-265, doi: 10.1016/j.emj.2008.01.006.

Wright, P., Ferris, S. (1997) "Agency Conflict and Corporate Strategy: The Effect of Divestment on Corporate Value", Strategic Management Journal Vol. 18, No. 1, pp. 77-83, doi: 10.1002/(SICI)1097-0266(199701).

Wu, ML. (2006) "Corporate Social Performance, Corporate Financial Performance and Firm Size", Journal of American Academy of Business, Vol. 8, No. 1, pp. 163-171. 


\title{
Mjerenje gospodarske uspješnosti društveno odgovornih poduzeća
}

\author{
Josefina Fernández-Guadaño ${ }^{1}$
}

\begin{abstract}
Sažetak
Cilj ovog istraživanja je korištenje različitih ekonomskih varijabli da bi se utvrdilo postoje li razlike u gospodarskoj uspješnosti poslovanja poduzeća kao rezultat njihova uključivanja u indeks održivosti. Rad predstavlja jednodimenzionalnu istraživačku studiju koja uspoređuje društveno-odgovorna poduzeća uključena $u$ španjolski indeks održivosti FTSE4Good Ibex s ostalim tvrtkama uključenim u indekse iz porodice IBEX. Parametarsko testiranje koristi se da bi se utvrdilo postoji li razlika između ta dva tipa poduzeća. Rezultati pokazuju da u ekonomskim rezultatima između dviju skupina nema statistički značajnih razlika. Također je potvrdeno da su poduzeća s dobrom praksom jednako profitabilna kao i druga, ali isto tako je utvrđeno da ekonomsko-financijsko ponašanje poduzeća nije bolje samim tim što je uključeno u indeks održivosti. Temeljni zaključak je da poštivanje društvenih i ekoloških standarda ne šteti konkurentnoj poziciji poduzeća, te stoga, svojim rezultatima pružaju podršku politici razvoja odgovornih praksi da bi postali alat za učvršćivanje povjerenja u gospodarstvo i investitore.
\end{abstract}

Ključne riječi: društvena odgovornost poduzeća (CRS), financijski rezultati poslovanja poduzeća (CFP), Španjolska, indeks održivosti, dobre prakse

JEL klasifikacija: M210, M400

1 Doktor ekonomskih znanosti, Finance Department, Faculty of Economics Sciences Complutense, University Campus de Somosaguas, Pabellón de Sexto. Despacho 46, E-28223 Pozuelo de Alarcón, Madrid, Španjolska. Znanstveni interes: korporacijske financije. Tel.: +34 913942330. E-mail:jofernan@ucm.es.Webstranica:http://www.ucm.es/ecfin3/fernandez-guadano,-josefina; http://pendientedemigracion.ucm.es/info/eec/DetalleComponente.php? IdDeComponente $=30$. 


\section{Appendix}

Table 1: Comparative statistics for differences in EBITDA/A

\begin{tabular}{|c|c|c|c|c|c|c|c|c|}
\hline Variable & Comparisons & year & statistic_t & parameter_df & p_value & sign & conf_int1 & conf_int2 \\
\hline \multirow{15}{*}{ EBITDA/A } & \multirow{5}{*}{$\begin{array}{l}\text { FTSE4Good IBEX } \\
\text { All vs IBEX All }\end{array}$} & 2009 & -0.89 & 42.14 & 0.38 & $\mathrm{~N}$ & -0.07 & 0.03 \\
\hline & & 2008 & -1.43 & 38.21 & 0.16 & $\mathrm{~N}$ & -0.10 & 0.02 \\
\hline & & 2007 & -1.59 & 41.77 & 0.12 & $\mathrm{~N}$ & -0.11 & 0.01 \\
\hline & & 2006 & -1.59 & 27.37 & 0.12 & $\mathrm{~N}$ & -0.11 & 0.01 \\
\hline & & 2005 & -2.22 & 28.51 & 0.03 & $\mathrm{~N}$ & -0.13 & -0.01 \\
\hline & \multirow{5}{*}{$\begin{array}{l}\text { FTSE4Good } \\
\text { IBEX-35 vs } \\
\text { IBEX-35 }\end{array}$} & 2009 & -0.90 & 22.98 & 0.38 & $\mathrm{~N}$ & -0.08 & 0.03 \\
\hline & & 2008 & -1.39 & 20.03 & 0.18 & $\mathrm{~N}$ & -0.12 & 0.02 \\
\hline & & 2007 & -1.10 & 19.03 & 0.29 & $\mathrm{~N}$ & -0.11 & 0.03 \\
\hline & & 2006 & -1.33 & 20.04 & 0.20 & $\mathrm{~N}$ & -0.12 & 0.03 \\
\hline & & 2005 & -1.76 & 15.90 & 0.10 & $\mathrm{~N}$ & -0.13 & 0.01 \\
\hline & \multirow{5}{*}{$\begin{array}{l}\text { FTSE4Good } \\
\text { IBEX-M vs } \\
\text { IBEX-M }\end{array}$} & 2009 & 0.48 & 8.67 & 0.65 & $\mathrm{~N}$ & -0.13 & 0.19 \\
\hline & & 2008 & -0.09 & 11.70 & 0.93 & $\mathrm{~N}$ & -0.15 & 0.14 \\
\hline & & 2007 & -0.86 & 10.34 & 0.41 & $\mathrm{~N}$ & -0.22 & 0.10 \\
\hline & & 2006 & -0.67 & 5.81 & 0.53 & $\mathrm{~N}$ & -0.28 & 0.16 \\
\hline & & 2005 & -1.60 & 6.25 & 0.16 & $\mathrm{~N}$ & -0.24 & 0.05 \\
\hline
\end{tabular}

Source: Author's calculation

Table 2: Comparative statistics for differences in VA/A

\begin{tabular}{|c|c|c|c|c|c|c|c|c|}
\hline Variable & Comparisons & year & statistic_t & parameter_df & p_value & sign & conf_int 1 & conf_int2 \\
\hline \multirow{15}{*}{$\mathrm{VA} / \mathrm{A}$} & \multirow{5}{*}{$\begin{array}{l}\text { FTSE4Good IBEX } \\
\text { All vs IBEX All }\end{array}$} & 2009 & 0.21 & 24.57 & 0.84 & $\mathrm{~N}$ & -0.11 & 0.14 \\
\hline & & 2008 & -0.29 & 30.53 & 0.78 & $\mathrm{~N}$ & -0.14 & 0.10 \\
\hline & & 2007 & -0.28 & 29.33 & 0.78 & $\mathrm{~N}$ & -0.13 & 0.10 \\
\hline & & 2006 & -0.53 & 22.87 & 0.60 & $\mathrm{~N}$ & -0.17 & 0.10 \\
\hline & & 2005 & -0.86 & 22.36 & 0.40 & $\mathrm{~N}$ & -0.17 & 0.07 \\
\hline & \multirow{5}{*}{$\begin{array}{l}\text { FTSE4Good } \\
\text { IBEX-35 vs } \\
\text { IBEX-35 }\end{array}$} & 2009 & 0.89 & 19.86 & 0.38 & $\mathrm{~N}$ & -0.06 & 0.15 \\
\hline & & 2008 & 0.39 & 20.07 & 0.70 & $\mathrm{~N}$ & -0.09 & 0.13 \\
\hline & & 2007 & 0.22 & 23.61 & 0.82 & $\mathrm{~N}$ & -0.10 & 0.12 \\
\hline & & 2006 & 0.09 & 23.86 & 0.93 & $\mathrm{~N}$ & -0.09 & 0.10 \\
\hline & & 2005 & -0.43 & 21.46 & 0.67 & $\mathrm{~N}$ & -0.11 & 0.07 \\
\hline & \multirow{5}{*}{$\begin{array}{l}\text { FTSE4Good } \\
\text { IBEX-M vs } \\
\text { IBEX-M }\end{array}$} & 2009 & -0.20 & 3.47 & 0.85 & $\mathrm{~N}$ & -0.85 & 0.74 \\
\hline & & 2008 & -0.51 & 5.23 & 0.63 & $\mathrm{~N}$ & -0.66 & 0.43 \\
\hline & & 2007 & -0.65 & 5.53 & 0.54 & $\mathrm{~N}$ & -0.60 & 0.35 \\
\hline & & 2006 & -0.90 & 3.52 & 0.43 & $\mathrm{~N}$ & -0.95 & 0.51 \\
\hline & & 2005 & -1.07 & 4.55 & 0.34 & $\mathrm{~N}$ & -0.70 & 0.30 \\
\hline
\end{tabular}

Source: Author's calculation 
Josefina Fernández-Guadaño • Measuring the economic performance of socially...

Zb. rad. Ekon. fak. Rij. • 2015 • vol. 33 • sv. $2 \cdot 207-233$

Table 3: Comparative statistics for differences in Profit per share

\begin{tabular}{|c|c|c|c|c|c|c|c|c|}
\hline Variable & Comparisons & year & statistic_t & parameter_df & p_value & sign & conf_int1 & conf_int2 \\
\hline \multirow{15}{*}{$\begin{array}{l}\text { Profit per } \\
\text { share }\end{array}$} & \multirow{5}{*}{$\begin{array}{l}\text { FTSE4Good IBEX } \\
\text { All vs IBEX All }\end{array}$} & 2009 & 0.93 & 51.89 & 0.36 & $\mathrm{~N}$ & -0.99 & 2.68 \\
\hline & & 2008 & 0.84 & 52.67 & 0.40 & $\mathrm{~N}$ & -0.90 & 2.20 \\
\hline & & 2007 & 0.04 & 66.58 & 0.97 & $\mathrm{~N}$ & -1.61 & 1.68 \\
\hline & & 2006 & -0.25 & 54.10 & 0.80 & $\mathrm{~N}$ & -1.35 & 1.04 \\
\hline & & 2005 & -0.44 & 44.30 & 0.66 & $\mathrm{~N}$ & -1.15 & 0.74 \\
\hline & \multirow{5}{*}{$\begin{array}{l}\text { FTSE4Good } \\
\text { IBEX-35 vs } \\
\text { IBEX-35 }\end{array}$} & 2009 & 1.25 & 10.33 & 0.24 & $\mathrm{~N}$ & -1.73 & 6.18 \\
\hline & & 2008 & 1.24 & 10.79 & 0.24 & $\mathrm{~N}$ & -1.12 & 3.99 \\
\hline & & 2007 & 0.85 & 15.16 & 0.41 & $\mathrm{~N}$ & -1.74 & 4.06 \\
\hline & & 2006 & 0.69 & 16.50 & 0.50 & $\mathrm{~N}$ & -1.30 & 2.57 \\
\hline & & 2005 & 0.66 & 13.20 & 0.52 & $\mathrm{~N}$ & -1.31 & 2.46 \\
\hline & \multirow{5}{*}{$\begin{array}{l}\text { FTSE4Good } \\
\text { IBEX-M vs } \\
\text { IBEX-M }\end{array}$} & 2009 & 1.16 & 11.05 & 0.27 & $\mathrm{~N}$ & -3.37 & 10.84 \\
\hline & & 2008 & 1.18 & 10.54 & 0.27 & $\mathrm{~N}$ & -2.93 & 9.58 \\
\hline & & 2007 & 0.66 & 10.69 & 0.52 & $\mathrm{~N}$ & -3.52 & 6.55 \\
\hline & & 2006 & 0.31 & 11.56 & 0.76 & $\mathrm{~N}$ & -2.17 & 2.90 \\
\hline & & 2005 & -0.04 & 12.03 & 0.97 & $\mathrm{~N}$ & -1.62 & 1.56 \\
\hline
\end{tabular}

Source: Author's calculation

Table 4: Comparative statistics for differences in ROA

\begin{tabular}{|c|c|c|c|c|c|c|c|c|}
\hline Variable & Comparisons & year & statistic_t & parameter_df & p_value & sign & conf_int1 & conf_int2 \\
\hline \multirow{15}{*}{ ROA } & \multirow{5}{*}{$\begin{array}{l}\text { FTSE4Good IBEX } \\
\text { All vs IBEX All }\end{array}$} & 2009 & -0.57 & 50.49 & 0.57 & $\mathrm{~N}$ & -5.74 & 3.19 \\
\hline & & 2008 & -1.18 & 61.39 & 0.24 & $\mathrm{~N}$ & -7.93 & 2.06 \\
\hline & & 2007 & -1.38 & 42.45 & 0.18 & $\mathrm{~N}$ & -10.00 & 1.88 \\
\hline & & 2006 & -1.59 & 26.80 & 0.12 & $\mathrm{~N}$ & -11.37 & 1.44 \\
\hline & & 2005 & -2.17 & 26.72 & 0.04 & S & -12.11 & -0.34 \\
\hline & \multirow{5}{*}{$\begin{array}{l}\text { FTSE4Good } \\
\text { IBEX-35 vs } \\
\text { IBEX-35 }\end{array}$} & 2009 & -0.70 & 18.64 & 0.49 & $\mathrm{~N}$ & -6.53 & 3.25 \\
\hline & & 2008 & -1.35 & 23.96 & 0.19 & $\mathrm{~N}$ & -7.71 & 1.62 \\
\hline & & 2007 & -1.06 & 18.18 & 0.30 & $\mathrm{~N}$ & -9.95 & 3.26 \\
\hline & & 2006 & -1.24 & 18.63 & 0.23 & $\mathrm{~N}$ & -10.92 & 2.79 \\
\hline & & 2005 & -1.53 & 14.70 & 0.15 & $\mathrm{~N}$ & -11.71 & 1.92 \\
\hline & \multirow{5}{*}{$\begin{array}{l}\text { FTSE4Good } \\
\text { IBEX-M vs } \\
\text { IBEX-M }\end{array}$} & 2009 & 1.13 & 7.74 & 0.29 & $\mathrm{~N}$ & -8.70 & 25.28 \\
\hline & & 2008 & 0.96 & 12.69 & 0.36 & $\mathrm{~N}$ & -8.34 & 21.60 \\
\hline & & 2007 & -0.26 & 10.75 & 0.80 & $\mathrm{~N}$ & -17.59 & 13.92 \\
\hline & & 2006 & -0.59 & 5.49 & 0.58 & $\mathrm{~N}$ & -29.06 & 18.01 \\
\hline & & 2005 & -1.43 & 5.49 & 0.21 & $\mathrm{~N}$ & -22.23 & 6.08 \\
\hline
\end{tabular}

Source: Author's calculation 
Table 5: Comparative statistics for differences in ROE

\begin{tabular}{|c|c|c|c|c|c|c|c|c|}
\hline Variable & Comparisons & year & statistic_t & parameter_df & p_value & sign & conf_int1 & conf_int 2 \\
\hline \multirow{15}{*}{ ROE } & \multirow{5}{*}{$\begin{array}{l}\text { FTSE4Good IBEX } \\
\text { All vs IBEX All }\end{array}$} & 2009 & -0.56 & 39.19 & 0.58 & $\mathrm{~N}$ & -19.73 & 11.18 \\
\hline & & 2008 & -0.87 & 47.41 & 0.39 & $\mathrm{~N}$ & -26.00 & 10.26 \\
\hline & & 2007 & -1.68 & 61.11 & 0.10 & $\mathrm{~N}$ & -27.16 & 2.38 \\
\hline & & 2006 & -1.75 & 36.24 & 0.09 & $\mathrm{~N}$ & -29.42 & 2.14 \\
\hline & & 2005 & -2.55 & 44.55 & 0.01 & S & -27.86 & -3.28 \\
\hline & \multirow{5}{*}{$\begin{array}{l}\text { FTSE4Good } \\
\text { IBEX-35 vs } \\
\text { IBEX-35 }\end{array}$} & 2009 & -0.67 & 15.23 & 0.51 & $\mathrm{~N}$ & -20.69 & 10.82 \\
\hline & & 2008 & -0.63 & 18.90 & 0.54 & $\mathrm{~N}$ & -21.24 & 11.39 \\
\hline & & 2007 & -0.87 & 23.82 & 0.40 & $\mathrm{~N}$ & -18.39 & 7.52 \\
\hline & & 2006 & -1.08 & 23.95 & 0.29 & $\mathrm{~N}$ & -16.05 & 5.01 \\
\hline & & 2005 & -0.22 & 19.98 & 0.83 & $\mathrm{~N}$ & -16.77 & 13.60 \\
\hline & \multirow{5}{*}{$\begin{array}{l}\text { FTSE4Good } \\
\text { IBEX-M vs } \\
\text { IBEX-M }\end{array}$} & 2009 & 1.01 & 4.95 & 0.36 & $\mathrm{~N}$ & -43.20 & 99.31 \\
\hline & & 2008 & 0.74 & 6.69 & 0.49 & $\mathrm{~N}$ & -49.21 & 93.05 \\
\hline & & 2007 & -0.23 & 10.70 & 0.82 & $\mathrm{~N}$ & -51.06 & 41.48 \\
\hline & & 2006 & -0.57 & 5.18 & 0.59 & $\mathrm{~N}$ & -103.83 & 65.55 \\
\hline & & 2005 & -1.49 & 4.89 & 0.20 & $\mathrm{~N}$ & -58.38 & 15.63 \\
\hline
\end{tabular}

Source: Author's calculation

Table 6: Comparative statistics for differences in solvency

\begin{tabular}{|c|c|c|c|c|c|c|c|c|}
\hline Variable & Comparisons & year & statistic_t & parameter_df & p_value & sign & conf_int1 & conf_int2 \\
\hline \multirow{15}{*}{$\begin{array}{l}\text { solvency_ } \\
\text { ratio }\end{array}$} & \multirow{5}{*}{$\begin{array}{l}\text { FTSE4Good IBEX } \\
\text { All vs IBEX All }\end{array}$} & 2009 & 0.89 & 32.50 & 0.38 & $\mathrm{~N}$ & -5.87 & 15.05 \\
\hline & & 2008 & 0.69 & 39.28 & 0.49 & $\mathrm{~N}$ & -6.37 & 13.03 \\
\hline & & 2007 & 0.50 & 37.49 & 0.62 & $\mathrm{~N}$ & -7.62 & 12.64 \\
\hline & & 2006 & 0.91 & 34.15 & 0.37 & $\mathrm{~N}$ & -5.75 & 15.10 \\
\hline & & 2005 & 0.69 & 40.57 & 0.50 & $\mathrm{~N}$ & -7.04 & 14.32 \\
\hline & \multirow{5}{*}{$\begin{array}{l}\text { FTSE4Good } \\
\text { IBEX-35 vs } \\
\text { IBEX-35 }\end{array}$} & 2009 & -0.48 & 22.40 & 0.64 & $\mathrm{~N}$ & -17.84 & 11.12 \\
\hline & & 2008 & -1.09 & 23.97 & 0.29 & $\mathrm{~N}$ & -21.92 & 6.81 \\
\hline & & 2007 & -1.40 & 23.07 & 0.18 & $\mathrm{~N}$ & -23.56 & 4.58 \\
\hline & & 2006 & -1.18 & 22.89 & 0.25 & $\mathrm{~N}$ & -21.32 & 5.87 \\
\hline & & 2005 & -1.35 & 22.86 & 0.19 & $\mathrm{~N}$ & -23.01 & 4.87 \\
\hline & \multirow{5}{*}{$\begin{array}{l}\text { FTSE4Good } \\
\text { IBEX-M vs } \\
\text { IBEX-M }\end{array}$} & 2009 & 1.01 & 7.27 & 0.35 & $\mathrm{~N}$ & -12.13 & 30.41 \\
\hline & & 2008 & 1.37 & 11.27 & 0.20 & $\mathrm{~N}$ & -6.94 & 30.09 \\
\hline & & 2007 & 0.61 & 11.36 & 0.55 & $\mathrm{~N}$ & -13.21 & 23.46 \\
\hline & & 2006 & 1.81 & 11.27 & 0.10 & $\mathrm{~N}$ & -2.52 & 26.47 \\
\hline & & 2005 & 0.93 & 12.82 & 0.37 & $\mathrm{~N}$ & -12.30 & 30.99 \\
\hline
\end{tabular}

Source: Author's calculation 
Josefina Fernández-Guadaño • Measuring the economic performance of socially...

Zb. rad. Ekon. fak. Rij. • 2015 • vol. 33 • sv. $2 \cdot 207-233$

Table 7: Comparative statistics for differences in Debt ratio

\begin{tabular}{|c|c|c|c|c|c|c|c|c|}
\hline Variable & Comparisons & year & statistic_t & parameter_df & p_value & sign & conf_int1 & conf_int2 \\
\hline \multirow{15}{*}{ Debt ratio } & \multirow{5}{*}{$\begin{array}{l}\text { FTSE4Good IBEX } \\
\text { All vs IBEX All }\end{array}$} & 2009 & -1.00 & 29.69 & 0.32 & $\mathrm{~N}$ & -0.16 & 0.05 \\
\hline & & 2008 & -0.76 & 35.93 & 0.45 & $\mathrm{~N}$ & -0.14 & 0.06 \\
\hline & & 2007 & -0.53 & 34.22 & 0.60 & $\mathrm{~N}$ & -0.13 & 0.08 \\
\hline & & 2006 & -0.91 & 34.15 & 0.37 & $\mathrm{~N}$ & -0.15 & 0.06 \\
\hline & & 2005 & -0.69 & 40.57 & 0.50 & $\mathrm{~N}$ & -0.14 & 0.07 \\
\hline & \multirow{5}{*}{$\begin{array}{l}\text { FTSE4Good } \\
\text { IBEX-35 vs } \\
\text { IBEX-35 }\end{array}$} & 2009 & 0.48 & 22.40 & 0.64 & $\mathrm{~N}$ & -0.11 & 0.18 \\
\hline & & 2008 & 1.09 & 23.97 & 0.29 & $\mathrm{~N}$ & -0.07 & 0.22 \\
\hline & & 2007 & 1.40 & 23.07 & 0.18 & $\mathrm{~N}$ & -0.05 & 0.24 \\
\hline & & 2006 & 1.18 & 22.89 & 0.25 & $\mathrm{~N}$ & -0.06 & 0.21 \\
\hline & & 2005 & 1.35 & 22.86 & 0.19 & $\mathrm{~N}$ & -0.05 & 0.23 \\
\hline & \multirow{5}{*}{$\begin{array}{l}\text { FTSE4Good } \\
\text { IBEX-M vs } \\
\text { IBEX-M }\end{array}$} & 2009 & -1.01 & 7.27 & 0.35 & $\mathrm{~N}$ & -0.30 & 0.12 \\
\hline & & 2008 & -1.37 & 11.27 & 0.20 & $\mathrm{~N}$ & -0.30 & 0.07 \\
\hline & & 2007 & -0.61 & 11.36 & 0.55 & $\mathrm{~N}$ & -0.23 & 0.13 \\
\hline & & 2006 & -1.81 & 11.27 & 0.10 & $\mathrm{~N}$ & -0.26 & 0.03 \\
\hline & & 2005 & -0.93 & 12.82 & 0.37 & $\mathrm{~N}$ & -0.31 & 0.12 \\
\hline
\end{tabular}

Source: Author's calculation

Table 8: Comparative statistics for differences in risk

\begin{tabular}{|c|c|c|c|c|c|c|c|c|}
\hline Variable & Comparisons & year & statistic_t & parameter_df & p_value & sign & conf_int1 & conf_int2 \\
\hline \multirow{15}{*}{ Beta } & \multirow{5}{*}{$\begin{array}{l}\text { FTSE4Good IBEX } \\
\text { All vs IBEX All }\end{array}$} & 2009 & -2.79 & 46.73 & 0.01 & S & -0.45 & -0.07 \\
\hline & & 2008 & -2.79 & 47.75 & 0.01 & $\mathrm{~S}$ & -0.44 & -0.07 \\
\hline & & 2007 & -2.83 & 48.12 & 0.01 & S & -0.44 & -0.07 \\
\hline & & 2006 & -3.28 & 42.59 & 0.00 & $\mathrm{~S}$ & -0.47 & -0.11 \\
\hline & & 2005 & -3.47 & 41.76 & 0.00 & $\mathrm{~S}$ & -0.49 & -0.13 \\
\hline & \multirow{5}{*}{$\begin{array}{l}\text { FTSE4Good } \\
\text { IBEX-35 vs } \\
\text { IBEX-35 }\end{array}$} & 2009 & -1.32 & 21.72 & 0.20 & $\mathrm{~N}$ & -0.38 & 0.09 \\
\hline & & 2008 & -1.23 & 21.15 & 0.23 & $\mathrm{~N}$ & -0.37 & 0.10 \\
\hline & & 2007 & -1.20 & 21.17 & 0.24 & $\mathrm{~N}$ & -0.37 & 0.10 \\
\hline & & 2006 & -1.53 & 20.88 & 0.14 & $\mathrm{~N}$ & -0.42 & 0.06 \\
\hline & & 2005 & -1.74 & 14.99 & 0.10 & $\mathrm{~N}$ & -0.47 & 0.05 \\
\hline & \multirow{5}{*}{$\begin{array}{l}\text { FTSE4Good } \\
\text { IBEX-M vs } \\
\text { IBEX-M }\end{array}$} & 2009 & -0.21 & 7.71 & 0.84 & $\mathrm{~N}$ & -0.53 & 0.45 \\
\hline & & 2008 & -0.29 & 7.95 & 0.78 & $\mathrm{~N}$ & -0.53 & 0.41 \\
\hline & & 2007 & -0.35 & 8.30 & 0.73 & $\mathrm{~N}$ & -0.52 & 0.38 \\
\hline & & 2006 & -0.37 & 8.74 & 0.72 & $\mathrm{~N}$ & -0.51 & 0.36 \\
\hline & & 2005 & -0.27 & 8.40 & 0.80 & $\mathrm{~N}$ & -0.49 & 0.39 \\
\hline
\end{tabular}

Source: Author's calculation 